\title{
CONSEQUENCES OF THE EXTIRPATION of Predators on Moose
}

\author{
JOEL BERGER $\uparrow$ CAROL CUNNINGHAM \\ PROGRAM IN EEC BIOLOGY $\downarrow$ UNIVERSITY OF NEVADA \\ RENO
}

\section{$\uparrow \quad$ SUMMARY}

This year was the first of our five year project. We established three primary study areas to examine possible biological effects of large predators on moose. Sites where fieldwork was conducted included apparent heavy predation by grizzly bears [the eastern slopes of the Talkeetna Mountains (Alaska)], little or no predation (Grand Teton National Park), and human predation (Bridger-Teton National Forest), the latter two in the southern portion of the Greater Yellowstone Ecosystem. Data were gathered in Alaska from April until August and, in Wyoming, for all months from February until August (except during April). At the southern Greater Yellowstone sites, information was collected on pregnancy rates, calf production, twinning, and juvenile and adult survivorship. Ecological and behavioral data gathered from all three sites included home range locations, foraging associations and rates, habitat use, group size, social interactions, migration, and responses to humans and potential predators. Twenty animals were radio-collared at the Wyoming site; as of December 1995 only 15 survived. One apparently starved to death, one was poached, one was legally shot, and two died of unknown causes. We improved our sample by using 13 females previously radio-collared on national forest lands by University of Wyoming and Wyoming Department of Game and Fish personnel. Of these, two died during the 1994-1995 winter and three had slipped their collars.
Plans for 1996 include fieldwork at all three sites. A field team will continue work in Alaska from April until August. In Wyoming, collars will be placed on animals using national forest lands (for a total of 10) and the park (5). Demographic, ecological, and behavioral data will be gathered at all sites, with fieldwork in Wyoming running from February until December.

\section{$\downarrow \quad$ INTRODUCTION}

Throughout much of the United States, large herbivore populations are regulated by human predation. Where natural non-human predators still exist, prey population density tends to be lower than in their absence. For example, moose and caribou tend to occur at lower densities where wolves are abundant. However, because potential predators such as grizzly bears and wolves have been lost from much of the lower United States and the habitats of many prey populations are now protected, large herbivore populations are now among the highest levels recorded during the 20th century. Our continuing research addresses the question: How does the loss of potentially dangerous predators affect the biology of moose?

The effects can be many, possibly involving demography, ecology, behavior, disease, even community structure, perhaps through excessive densities in riparian zones. Our research involves examination of the first three of these factors. If additional funding becomes available, the scope can be expanded to examine the latter. 


\section{PROGRESS-TO-DATE: DEMOGRAPHY}

Demographic data from Alaska are being coordinated by Dr. Ward Testa. Between 60-70\% of Alaskan calves have died before two months of age. In Wyoming, no mortality was recorded among known calves although it is likely that some births (and hence deaths) were not detected. Nevertheless, of the calves born in May and June 1995, all survived by the time summer fieldwork terminated.

1) Calf production and survivorship. During winter 1994-95, 60\% of the adult cows $(\mathrm{N}=17)$ in Grand Teton National Park (GTNP) were accompanied by yearlings (=calves born during 1994). Of these adult cows, $71 \%$ were pregnant and a minimum of $42 \%$ produced calves, of which $100 \%$ survived through the summer.

On Bridger-Teton National Forests lands (specifically, those females radio-collared previously in the Grey's River area), $100 \%$ of the adult cows $(\mathrm{N}=7)$ during the winter 1994-95 were accompanied by yearlings. Pregnancy rates were unknown but two of the four females produced calves, both which survived the summer. Because the three other females were not re-sighted it was impossible to know if they produced calves.

2) Twinning Rates. Twinning rates for respective study areas are: Bridger-Teton National Forest - 5.9\% [composite of 1/16 (1994-95) yearlings, and $1 / 18$ (1995) mother-calf associations]; and GTNP - 5.4\% [composite of $1 / 21$ (1994-95) yearlings, and $2 / 35$ mother-calf associations].

3) Female Age Structure.- Data are not currently available on population structure but we are trying to determine population profiles by developing a method to estimate age of live animals. During immobilization, all incisors are measured for height, width and thickness. The lower jaws of known, winter-kill and hunter-related mortalities are being gathered to determine how best to relate toothsize traits of known-aged animals (determined by cementum annuli) to those where only body measurements are available. The goal here is to develop fecundity profiles of known-aged animals at respective study areas.
1996 PLANS

A) Timing: During 1996, fieldwork will be conducted at all three sites as follows:

Alaska - April until August (Berger during April only; field team from May until August);
Wyoming- February until December (Berger and Cunningham rotating between Gray's River and GTNP sites)

B) Immobilization and Radio-Collars:

During February we plan to place 15 radiocollars on females as follows:

- Gray's River Region - 10 [Note: several of these will be replacements of animals previously collared and may include, for example, \#148.171 (land between Black Cyn and Snake River), 148.301 (between Elk and Bradley Mtn), 148.331 (lower Mosquito Creek), 148.341 (e. Gros Ventre Butte)]

- GTNP - 5 [Note: from replacements for animals that died in 1995 along the Buffalo Fork, and Ditch Creek, Gros Ventre drainages]

C) Ecological, Behavioral, and Demographic Data

We will continue to gather data on pregnancy rates (via laboratory analyses of fecal steroids), calf production and survival, adult mortality, and calf (and yearling) growth rates. Ecological data will include assessment of home range and seasonal movements, habitat use, and simple vegetation parameters. Behavioral data will involve foraging and grouping associations, responses to playback of sounds, smells, and sights of potential predators, mother-young relationships, and dominance interactions.

\section{$\uparrow \quad$ ACKNOWLEDGMENTS}

For permission to do this study and help we appreciate the efforts of Alaska Department of Fish and Game, National Elk Refuge, U. S. Forest Service, U. S. National Park Service, Wyoming Department of Game and Fish. For grant-related support we thank the Hasselblad Foundation 
(Sweden), National Park Service, University of Wyoming-NPS Research Center, Wildlife Conservation Society, and the University of Nevada. For discussions, comments, insights, and logistical coordination we are most grateful to: Joe Bohne, Terry Bowyer, Bob and Bette Caesar, Steve Cain, Franz Camenzind, Don Deering, Gary Frahlich, Hank Harlow, Mike Hedrick, Penny Maldonado, Mark Mastellar, Bill Noblitt, Bob and Chris Schiller, Bruce Smith, and Ward Testa. 